\title{
Efficient Comparative Analysis Of Fertilizers Palm Oil
}

\author{
Bayu Febriadi ${ }^{1}$, Anisya ${ }^{2}$, Pandu Pratama Putra ${ }^{3}$ \\ ${ }^{1,3}$ Department of Information System, Faculty of Computer Science, Universitas \\ Lancang Kuning, Indonesia \\ ${ }^{2}$ Department of Informatics Engineering, Institut Teknologi Padang, West \\ Sumatra, Indonesia \\ bayufebriadi@gmail.com
}

\begin{abstract}
Palm oil is a vegetable oil-producing plant that has more advantages compared to other vegetable oil-producing plants, which have high productivity reaching 4 tons ha-1 Crude Palm Oil (CPO). Palm oil is also a raw material for making food and non-food ingredients, and renewable fuels. The author wants to make an analysis by comparing two methods, namely the AHP Method (Analytical Hierarchy Process) and Fuzzy logic which is able to handle the uncertainty and uncertainty used. Fuzzy logic used is the Fuzzy Tsukamoto inference system because this method uses monotonous value applications, the output of the inference output from each rule is explicitly given (crisp) based on $\alpha$ predicate (fire strength). Whereas the AHP Method can facilitate in calculating the validity to the tolerance level of concentration as criteria and alternatives chosen by the user.
\end{abstract}

Keywords: Efficient Palm Oil Fertilizer, AHP, and Fuzzy Tsukamoto.

\section{Introduction}

The oil palm is a vegetable oil which has more advantages when compared to the oilseed plant to another, which has a high productivity reaches 4 tons ha-1 Crude Palm Oil (CPO), the economic life of a long and easy adapt to its environment. Palm oil is also the raw material for food and non-food and renewable fuels (renewable). Based on observations and interviews with Mr. Rihartono as the owner of CV. Bryant, in the way of oil fertilization of variation way or different for each age of the tree. For example, the palm trees aged 0 to 3 years old have different types of fertilizer with palm trees older than 3 years. On the palm trees that were 3 years old, fertilizer used is urea given two times in one year. Fertilizer KCL, given two times a year. Differences fertilizer for each crop is done because as all know that every fertilizer containing composition and content are different, so that's why fertilizers applied on the trees are different, the age of oil is very note before fertilizing because the older a palm tree then diminishing its fruit production. From the results of a brief interview with Mr. Rihartono hopes that applied this application can help in determining and efficient fertilizer given criteria. Of the problems that is described in the background then be formulated as follows: in order to manufacture more effective and the problems encountered are not too broad it is necessary to limit the problem as follows:

1. The variables used are: spacious gardens, number of Trees, Yields, Soil moisture, Age of Oil Palm, Seed type

2. Not about the Pest and Plant Pest Organisms (OPT).

3. Selection of fertilizers based on the age of the palm oil.

How to implement methods AHP (Analytical Hierarchy Process) and Tsukamoto fuzzy logic to analyze the oil palm fertilizer efficient at PT. Bryant? 


\section{Research Methodology}

\subsection{Theory And Hypotheses (If Required)}

Fuzzy Tsukamoto method is an extension of monotonous reasoning, in the Tsukamoto method every consequence of the rules in the form of IF-THEN must be presented with fuzzy sets with monotonous membership functions. As a result, the output of the conclusion of each rule is given explicitly (crisp) based on $\alpha$-predicate (strength of fire). The final results are obtained using a weighted average. Fuzzy logic is used to anticipate this in the selection of fertilizer. The choice of type of fertilizer can be included in 2 different sets, organic and urea, urea and SP36, and so on. How much of its presence in the set can be seen in the value of the membership that will be processed. In the fuzzy set, the selection of types of organic fertilizers, urea and SP36 can be described as follows:

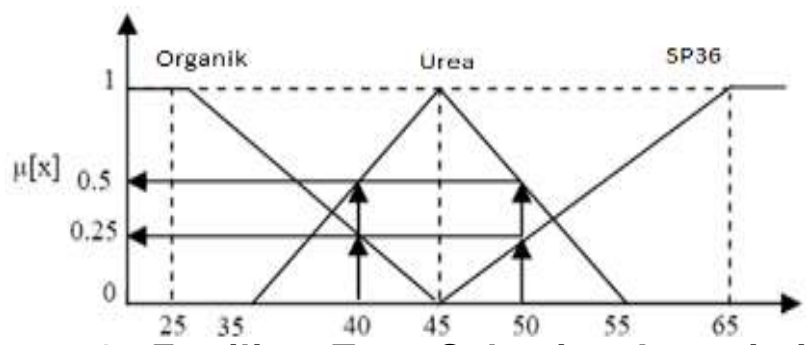

Figure 1. Fertilizer Type Selection Association

\subsection{Analytical Hierarchy Process}

Analytical Hierarchy Process (AHP) is a method of decision making by making pairwise comparisons between selection criteria and also pairwise comparisons between available choices. The problem of decision making with AHP is generally composed into criteria, and alternative choices.

\begin{tabular}{|c|c|c|c|c|}
\hline Alternatif & $\mathbf{1}$ & $\mathbf{2}$ & $\mathbf{3}$ & $\mathbf{n}$ \\
\hline $\mathbf{1}$ & & $\ldots . / \ldots$ & $\ldots / \ldots$ & $\ldots . \ldots / \ldots$ \\
\hline $\mathbf{2}$ & & & $\ldots / \ldots$ & $\ldots . / \ldots$ \\
\hline $\mathbf{3}$ & & & & $\ldots . / \ldots$ \\
\hline $\mathbf{n}$ & & & & \\
\hline
\end{tabular}

Figure 2. Comparison Matrix

\subsection{Research Methods}

The research methodology and research framework used in the completion of this study. This framework is the steps to be taken in order to solve the problem which will be discussed. The stages in the modeling used are Waterfall modeling, and can be seen in the picture below:

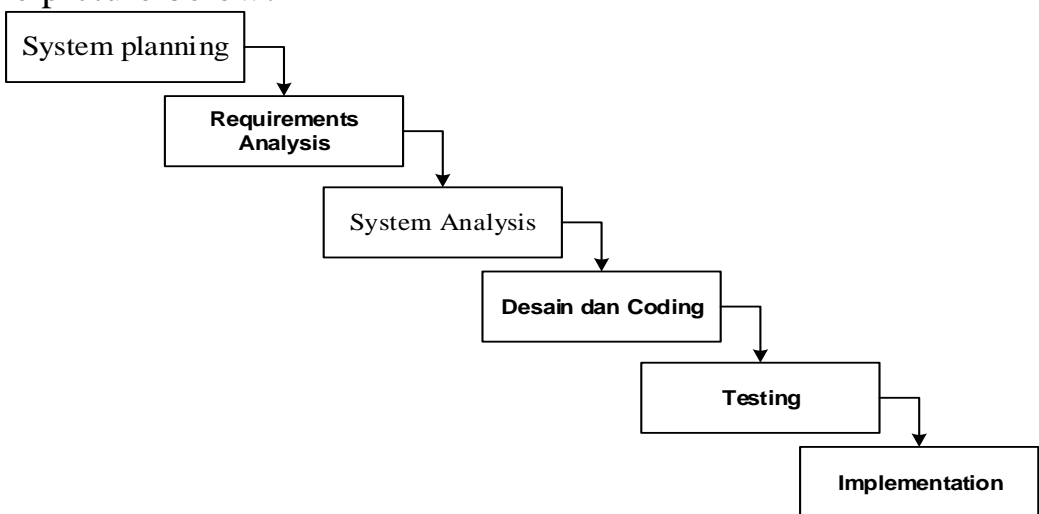

Figure 3. Waterfal Model Stages 
1) System Planning

This modeling begins with looking for the needs of the entire system that will be applied in the form of software. This is very important, reminding software to be able to interact with other elements such as hardware, databases, and so on. This stage is often called project definition. System design begins with conducting research on the elements - the elements of the system requirements in question and defining the needs - needs in the implementation of applications that are able to compare the results of analysis of fertilizers palm oil efficiently between AHP (Analytical Hierarchy Process) and Tsukamoto fuzzy logic at PT. Bryant.

2) Requirements Analysis

The search process needs to be intensified in the software. To find out the nature of the program to be created, the software engineers must understand the domain of information from the software. By collecting data needs by application that are able to compare the results of analysis of fertilizers palm oil efficiently be tween AHP (Analytical Hierarchy Process) and Tsukamoto fuzzy logic in the PT. Bryant.

3) System Analysis

System Analysis is the decomposition of an intact system into its component activities, with the intention of identifying and evaluating problems, opportunities, constraints, occurring and expected needs so that improvements can be proposed in the implementation at PT. Bryant.

4) Design Systems

System Design is an implementation design preparation that describes how a system is formed in the form of depiction, planning and making sketches or arrangements of several separate elements into a single unit that is intact and functioning, involving the configuration of software and hardware components of a system.

5) Coding

In this case, this is a computer, so the design must be transformed into a form that can be understood by the machine, namely into the programming language through the coding process.

6) Testing

Something that is made must be tested and the results must be truly in accordance with the needs that have been previously defined.

7) Implementasi

The implementation stage is the stage where all system elements and activities are combined with the following steps:

a) Preparing Physical Facilities

Physical facilities that are prepared include computers and peripherals, including physical security to keep the equipment going for a long time.

b) Prepare the user

The user is prepared in advance, namely by providing procedural training as well as a tutorial on information systems according to their task functions. The aim is for users to understand and control system operations and how the system works and what is obtained from the system.

\section{Results and Discussion}

\subsection{Tsukamoto Fuzzy Logic}

In Tsukamoto Fuzzy Logic, each consequent upon the rules in the form of IFThen shall be represented by a fuzzy set with membership function monotonous. As a result, output inference result of each rule is given explicitly (crisp) by $\alpha$-predicate (fire strength). The end result is obtained by using a weighted average. 
Tabel 1. Total content of Hara Each combination Fertilizer

\begin{tabular}{|c|c|c|c|c|}
\hline \multirow{2}{*}{ No. } & The combination of fertilizer (kg / ha) & \multicolumn{3}{|c|}{ The total content of Hara (kg) } \\
\cline { 3 - 5 } & & $\mathbf{N}$ & $\mathbf{P}$ & $\mathbf{K}$ \\
\hline 1 & Urea $\mathrm{KCl} 248+40+160+50$ DSP SP36 & 597.6 & 75.36 & 169.2 \\
\hline 2 & Urea $\mathrm{KCl} 248+50+170+40$ DSP SP36 & 254 & 416.8 & 63.63 \\
\hline 3 & 250 Urea $\mathrm{KCl}+150+30+50$ DSP SP36 & 387 & 230.86 & 121116 \\
\hline 4 & 250 Urea $\mathrm{KCl}+180+50+30$ DSP SP36 & 183.6 & 78108 & 210.66 \\
\hline
\end{tabular}

Tabel 2. Total Content of NPK Information: Values of N, P and $K$ are obtained from the calculation results with the following provisions

\begin{tabular}{|c|c|c|c|c|c|c|c|}
\hline The content / Fertilizer & $\mathrm{N}$ & $\mathrm{P}$ & $\mathrm{K}$ & UREA & KCL & SP36 & DSP \\
\hline urea & 1.2 & 0.3 & 0.8 & 248 & 40 & 160 & 50 \\
\hline KCL & 0.5 & 1.6 & 0.3 & 248 & 50 & 170 & 40 \\
\hline SP36 & 0.86 & 1 & 0.6 & 250 & 30 & 150 & 50 \\
\hline DSP & 0.36 & 0.3 & 1 & 250 & 50 & 180 & 30 \\
\hline $\mathrm{V}(\mathrm{N})$ & $\mathbf{V}(\mathbf{P})$ & $\mathbf{V}(\mathbf{K})$ & $\mathbf{G}(\mathbf{N})$ & $\mathbf{G}(\mathbf{P})$ & \multirow{2}{*}{\multicolumn{3}{|c|}{$\begin{array}{l}\mathbf{G}(\mathbf{K}) \\
1602\end{array}$}} \\
\hline 1.2 & 0.3 & 0.8 & 597.6 & 75.36 & & & \\
\hline 0.5 & 1.6 & 0.3 & 254 & 416.8 & \multicolumn{3}{|c|}{63.63} \\
\hline 0.86 & 1 & 0.6 & 387 & 230.86 & \multicolumn{3}{|c|}{121116} \\
\hline $0: 36$ & 0.3 & 1 & 183.6 & 78108 & & \multicolumn{2}{|c|}{210.66} \\
\hline
\end{tabular}

Tabel 3. Fertilizer Prices Combination

\begin{tabular}{|c|c|c|c|}
\hline No. & The combination of fertilizer $(\mathbf{k g} / \mathbf{h a})$ & Price & Price \\
\cline { 3 - 4 } & & (USD) & (USD / kg) \\
\hline 1 & Urea $\mathrm{KCl} 248+40+160+50$ DSP SP36 & 902400 & 2,014 \\
\hline 2 & Urea $\mathrm{KCl} 248+50+170+40$ DSP SP36 & 947400 & 2,024 \\
\hline 3 & 250 Urea $\mathrm{KCl}+150+30+50$ DSP SP36 & 861000 & 2,002 \\
\hline 4 & 250 Urea $\mathrm{KCl}+180+50+30$ DSP SP36 & 974000 & 2,029 \\
\hline
\end{tabular}

Tabel 4. Limit Terms of Use Hara

\begin{tabular}{|c|c|c|c|}
\hline Fertilizer & $\mathbf{N}$ & $\mathbf{P}$ & $\mathbf{K}$ \\
\hline Min & 50 & 30 & 15 \\
\hline Max & 925 & 345 & 330 \\
\hline
\end{tabular}

Tabel 5. Data Relationships Fertilizer

\begin{tabular}{|c|c|c|c|c|c|c|c|}
\hline \multirow[t]{2}{*}{ No. } & \multirow{2}{*}{$\begin{array}{l}\text { Name } \\
\text { Fertilizer }\end{array}$} & \multicolumn{6}{|c|}{ Criteria } \\
\hline & & $\begin{array}{l}\text { spacious } \\
\text { gardens }\end{array}$ & $\begin{array}{l}\text { number } \\
\text { of } \\
\text { Trees }\end{array}$ & Yields & $\begin{array}{l}\text { Soil } \\
\text { moisture }\end{array}$ & $\begin{array}{l}\text { Age of Oil } \\
\text { Palm }\end{array}$ & $\begin{array}{l}\text { Seed } \\
\text { type }\end{array}$ \\
\hline 1 & $\begin{array}{l}\text { Urea } \\
\text { fertilizer }\end{array}$ & $\begin{array}{l}0.3 \mathrm{Ha} \\
<>1 \mathrm{~kg}\end{array}$ & $\begin{array}{l}1 \mathrm{Kg}<> \\
1-3 \mathrm{Btg}\end{array}$ & $\begin{array}{l}8 \text { Tons / } \\
\text { Month }\end{array}$ & $104.3 \mathrm{pH}$ & $\begin{array}{l}1-12 \\
\text { Years }\end{array}$ & ordinary \\
\hline 2 & $\begin{array}{l}\text { SP-36 } \\
\text { fertilizer }\end{array}$ & $\begin{array}{l}0: 28 \mathrm{Ha} \\
<>1 \mathrm{~kg}\end{array}$ & $\begin{array}{l}1 \mathrm{Kg}<> \\
1-3 \mathrm{Btg}\end{array}$ & $\begin{array}{l}8.5 \text { Tons / } \\
\text { Month }\end{array}$ & pH 97.1 & $\begin{array}{l}1-12 \\
\text { Years }\end{array}$ & ordinary \\
\hline 3 & $\begin{array}{l}\text { fertilizer } \\
\text { DSP }\end{array}$ & $\begin{array}{l}0: 28 \mathrm{Ha} \\
<>1 \mathrm{~kg}\end{array}$ & $\begin{array}{l}1 \mathrm{Kg}<> \\
1-3 \mathrm{Btg}\end{array}$ & $\begin{array}{l}7.5 \text { Tons / } \\
\text { Month }\end{array}$ & pH 87.5 & $\begin{array}{l}1-12 \\
\text { Years }\end{array}$ & ordinary \\
\hline 4 & $\begin{array}{l}\text { fertilizer } \\
\text { KCL }\end{array}$ & $\begin{array}{l}0: 26 \mathrm{Ha} \\
<>1 \mathrm{~kg}\end{array}$ & $\begin{array}{l}1 \mathrm{Kg} \ll \\
1-3 \mathrm{Btg}\end{array}$ & $\begin{array}{l}\text { 7.9 Tons / } \\
\text { Month }\end{array}$ & pH 95.5 & $\begin{array}{l}1-12 \\
\text { Years }\end{array}$ & Superior \\
\hline
\end{tabular}

Tabel 6. Dosing Fertilizer

\begin{tabular}{|c|c|c|c|c|}
\hline \multirow{2}{*}{ Age of Oil Palm } & \multicolumn{4}{|c|}{ MEASURING PER TREE (Kg) } \\
\cline { 2 - 5 } & UREA & SP 36 & KCL & DSP \\
\hline 13 years old & $0.5 \mathrm{~kg}$ & 0.5 to $0.75 \mathrm{~kg}$ & $0.25 \mathrm{~kg}$ & 0.5 to $1 \mathrm{~kg}$ \\
\hline 35 years old & 0.5 to $1 \mathrm{~kg}$ & 0.5 to $1 \mathrm{~kg}$ & 0.25 to $0.5 \mathrm{~kg}$ & 0.5 to $1 \mathrm{~kg}$ \\
\hline 6-12 years & 0.5 to $1 \mathrm{~kg}$ & 0.5 to $1 \mathrm{~kg}$ & $0.25-0.5 \mathrm{~kg}$ & 0.5 to $1 \mathrm{~kg}$ \\
\hline $12-25$ years & 0.75 to $1.5 \mathrm{~kg}$ & 0.5 to $1 \mathrm{~kg}$ & 0.75 to $1 \mathrm{~kg}$ & 0.5 to $1 \mathrm{~kg}$ \\
\hline
\end{tabular}


Tabel 7. Value Criteria

\begin{tabular}{|c|c|c|c|c|c|}
\hline spacious gardens & number of Trees & Yields & Soil moisture & Age of Oil Palm & Seed type \\
\hline $12 \%$ & $17 \%$ & $23 \%$ & $13 \%$ & $18 \%$ & $17 \%$ \\
\hline
\end{tabular}

Tabel 8. Maximum Value Criteria

\begin{tabular}{|c|c|c|c|c|}
\hline Palm oil age & \multicolumn{4}{|c|}{ Maximum value } \\
\cline { 2 - 5 } & UREA & SP 36 & KCL & DSP \\
\hline 13 years old & $0: 50$ & 0.75 & $0: 25$ & 1 \\
\hline 35 years old & 1 & 1 & $0: 25$ & 1 \\
\hline 6-12 years & 1 & 1 & 0.5 & 1 \\
\hline 12-25 years & 1.5 & 1 & 1 & 1 \\
\hline
\end{tabular}

Tabel 9. Results of Efficiency

\begin{tabular}{|c|c|c|c|c|c|c|}
\hline Fertilizer / Value & $\begin{array}{l}\text { Spacious } \\
\text { Gardens }\end{array}$ & $\begin{array}{l}\text { Number } \\
\text { of Trees }\end{array}$ & Yields & $\begin{array}{l}\text { Soil } \\
\text { Moisture }\end{array}$ & $\begin{array}{l}\text { Age } \\
\text { Of Oil } \\
\text { Palm }\end{array}$ & $\begin{array}{l}\text { Seed } \\
\text { Type }\end{array}$ \\
\hline Urea fertilizer & $0: 06$ & 1 & $0: 23$ & 0195 & $0: 18$ & $0: 17$ \\
\hline SP-36 fertilizer & $0: 13$ & $1: 00$ & $0: 23$ & $0: 13$ & $0: 18$ & $0: 17$ \\
\hline fertilizer DSP & $1: 00$ & $1: 00$ & $1: 00$ & $1: 00$ & $0: 18$ & $0: 17$ \\
\hline fertilizer KCL & $0: 03$ & 0.0425 & 0115 & $0: 13$ & $0: 18$ & $0: 17$ \\
\hline
\end{tabular}

Tabel 10. Table Total Value

\begin{tabular}{|r|l|r|c|}
\hline No. & Name Fertilizer & Total value & Ranking \\
\hline 1 & Urea fertilizer & 1.84 & 3 \\
\hline 2 & SP-36 fertilizer & 1.84 & 2 \\
\hline 3 & fertilizer DSP & $4: 35$ & 1 \\
\hline 4 & fertilizer KCL & 0.67 & 4 \\
\hline
\end{tabular}

Table 10 Table Total Value conclusion: From the sample data above, it can take the conclusion that the efficient use of fertilizer is fertilizer DSP and Seling 3-4 Year Use fertilizers SP-36.

\subsection{AHP (Analytical Hierarchy Process)}

\section{a) Criteria}

In AHP are the criteria needed to determine the fertilizer that will be used. And The criteria given are as follows:

\section{Tabel 11. Criteria}

\begin{tabular}{|c|l|c|}
\hline Criteria & \multicolumn{1}{|c|}{ Information } & weights Criteria \\
\hline K1 & spacious gardens & $0: 12$ \\
\hline K2 & number of Trees & $0: 17$ \\
\hline K3 & Yields & $0: 23$ \\
\hline K4 & Soil moisture & $0: 13$ \\
\hline K5 & Age of Oil Palm & $0: 18$ \\
\hline K6 & Seed type & $0: 17$ \\
\hline
\end{tabular}

b) Determining the priority criteria

Steps to be taken in determining priority criteria are as follows

1) Creating a pairwise comparison matrix

Tabel 12. airwise Comparison Matrix

\begin{tabular}{|l|c|c|c|c|c|c|}
\hline Criteria & K1 & K2 & K3 & K4 & K5 & K6 \\
\hline K1 & 1 & 3 & 3 & 4 & 5 & 6 \\
\hline K2 & $0: 33$ & 1 & 1 & 2 & 3 & 3 \\
\hline K3 & $0: 33$ & 1 & 1 & 2 & 3 & 3 \\
\hline K4 & $0: 25$ & 0.5 & 0.5 & 1 & 2 & 1 \\
\hline
\end{tabular}




\begin{tabular}{|l|c|c|c|c|c|c|}
\hline Criteria & K1 & K2 & K3 & K4 & K5 & K6 \\
\hline K5 & 0.2 & $0: 33$ & $0: 33$ & 0.5 & 1 & 2 \\
\hline K6 & $0: 16$ & 0.5 & 0.5 & 0.6 & 0.83 & 1 \\
\hline amount & $2: 17$ & $6: 33$ & $6: 33$ & 10.1 & 14.83 & 16 \\
\hline
\end{tabular}

2) Create a matrix of criteria values

Tabel 13. Matrix Value Criteria

\begin{tabular}{|l|c|c|c|c|c|c|r|r|}
\hline & K1 & K2 & K3 & K4 & K5 & K6 & Amount & Priority \\
\hline K1 & 0.47 & 0.51 & 0.51 & 0.42 & 0.36 & 0.38 & 2.65 & 0.44166667 \\
\hline K2 & 0.16 & 0.17 & 0.17 & 0.21 & 0.21 & 0.19 & 1.11 & 0.185 \\
\hline K3 & 0.16 & 0.17 & 0.17 & 0.21 & 0.21 & 0.19 & 1.11 & 0.185 \\
\hline K4 & 0.12 & 0.09 & 0.09 & 0.1 & 0.14 & 0.06 & 0.6 & 0.1 \\
\hline K5 & 0.09 & 0.06 & 0.06 & 0.05 & 0.07 & 0.13 & 0.46 & 0.07666667 \\
\hline K6 & 0.07 & 0.08 & 0.08 & 0.06 & 0.06 & 0.06 & 0.41 & 0.06833333 \\
\hline
\end{tabular}

3) Creating a summation matrix each row

Tabel 14. Matrix Summation Each Line

\begin{tabular}{|r|c|c|c|c|c|c|r|}
\hline & K1 & K2 & K3 & K4 & K5 & K6 & Amount \\
\hline K1 & 0.44166667 & 1.325 & 1.325 & 1.766666667 & 2.20833334 & 2.65 & 9.716667 \\
\hline K2 & 0.06105 & 0.185 & 0.185 & 0.37 & 0.555 & 0.555 & 1.91105 \\
\hline K3 & 0.06105 & 0.185 & 0.185 & 0.37 & 0.555 & 0.555 & 1.91105 \\
\hline K4 & 0,025 & 0.05 & 0.05 & 0.1 & 0.2 & 0.1 & 0.525 \\
\hline K5 & 0.01533333 & .0253 & .0253 & 0.03833333 & 0.07666667 & 0.15333333 & 0.334267 \\
\hline K6 & 0.01093333 & 0.03416667 & 0.03416667 & 0,041 & 0.05671667 & 0.06833333 & 0.245317 \\
\hline
\end{tabular}

4) Calculation of the ratio of consistency

Tabel 15. The Ratio Of Consistency

\begin{tabular}{|c|c|c|c|}
\hline & Number Per Row & Priority & Result \\
\hline K1 & 9.716666674 & 0.441666667 & 9.716666667 \\
\hline K2 & & & \\
\hline K3 & 1.9 & 0.185 & 1.91105 \\
\hline K4 & 0.525 & 0.1 & 0.525 \\
\hline K5 & 0.334266668 & 0.076666667 & 0.33426667 \\
\hline K6 & 0.245316665 & 0.068333333 & 0.24531667 \\
\hline \multicolumn{3}{|c|}{ Amount } & 14.64335 \\
\hline
\end{tabular}

\subsection{Fertilizer of palm oil Efficiency Results}

From the results of the study authors suitable method for fertilizer efficiency is Fuzzy because the fuzzy method of calculation criteria based on the criteria that have value weighted and calculation of the direction taken by the value of each criterion, the following is a comparison table of fuzzy methods and AHP:

Tabel 16. Comparison of Methods of Fuzzy and AHP

\begin{tabular}{|c|l|l|l|}
\hline No. & Comparison & Fuzzy & AHP \\
\hline 1 & $\begin{array}{l}\text { Penelilaian criteria based } \\
\text { on the importance of the } \\
\text { criteria }\end{array}$ & $\begin{array}{l}\text { Taken from the } \\
\text { percentage of interest } \\
\text { criteria }\end{array}$ & $\begin{array}{l}\text { Values were taken from } \\
\text { the scale of assessment } \\
\text { criteria paired comparison }\end{array}$ \\
\hline 2 & Value Decisions & $\begin{array}{l}\text { The total value of the } \\
\text { criteria and gritting }\end{array}$ & $\begin{array}{l}\text { Results of comparative } \\
\text { criteria and gritting }\end{array}$ \\
\hline 3 & Calculation & $\begin{array}{l}\text { The maximum value } \\
\text { criteria }\end{array}$ & $\begin{array}{l}\text { The results of the } \\
\text { comparison value table }\end{array}$ \\
\hline
\end{tabular}


Tabel 17. Table Efficiency Fertilizer Fuzzy Method

\begin{tabular}{|c|c|c|c|c|c|c|}
\hline $\begin{array}{c}\text { Fertilizer } / \\
\text { Value }\end{array}$ & $\begin{array}{c}\text { Spacious } \\
\text { Gardens }\end{array}$ & $\begin{array}{c}\text { Number } \\
\text { of Trees }\end{array}$ & Yields & $\begin{array}{c}\text { Soil } \\
\text { Moisture }\end{array}$ & $\begin{array}{c}\text { Age of Oil } \\
\text { Palm }\end{array}$ & $\begin{array}{c}\text { Seed } \\
\text { Type }\end{array}$ \\
\hline Urea Fertilizer & $0: 06$ & 1 & $0: 23$ & 0195 & $0: 18$ & $0: 17$ \\
\hline Sp-36 Fertilizer & $0: 13$ & 1 & $0: 23$ & $0: 13$ & $0: 18$ & $0: 17$ \\
\hline Fertilizer Dsp & 1 & 1 & 1 & 1 & $0: 18$ & $0: 17$ \\
\hline Fertilizer Kcl & $0: 03$ & 0.0425 & 0115 & $0: 13$ & $0: 18$ & $0: 17$ \\
\hline
\end{tabular}

Tabel 18. Table Summation AHP Fertilizer Efficiency Result

\begin{tabular}{|c|c|c|c|c|c|c|}
\hline Fertilizer / Value & K1 & K2 & K3 & K4 & K5 & K6 \\
\hline Urea fertilizer & 0.44166667 & 1.325 & 1.325 & $176,666,667$ & $220,833,334$ & 2.65 \\
\hline SP-36 fertilizer & 0.06105 & 0.185 & 0.185 & 0.37 & 0.555 & 0.555 \\
\hline fertilizer DSP & 0.06105 & 0.185 & 0.185 & 0.37 & 0.555 & 0.555 \\
\hline fertilizer KCL & 0,025 & 0.05 & 0.05 & 0.1 & 0.2 & 0.1 \\
\hline
\end{tabular}

\section{Conclusion}

Based on the calculation of the criteria that have been implemented at PT Bryant, then using the Tsukamoto Fuzzy method is better in analyzing the use of oil palm fertilizers.

\section{References}

[1] Author 1, A.B.; Author 2, C.D. (Year). Title of the article. Abbreviated Journal Name, Volume, page range, DOI.

[2] Author 1, A.; Author 2, B. (2007). Title of the chapter. In Book Title, 2nd ed.; Editor 1, A., Editor 2, B., Eds.; Publisher: Publisher Location, Country, Volume 3, pp. 154-196, ISBN.

[3] Author 1, A.; Author 2, B. (2008). Book Title, 3rd ed.; Publisher: Publisher Location, Country, pp. 154-196, ISBN.

[4] Author 1, A.B. (University, City, State, Country); Author 2, C. (Institute, City, State, Country). (Year). Personal communication,

[5] Author 1, A.B.; Author 2, C.D.; Author 3, E.F. (2012). Title of Presentation. In Title of the Collected Work (if available), Proceedings of the Name of the Conference, Location of Conference, Country, Date of Conference; Editor 1, Editor 2, Eds. (if available); Publisher: City, Country, Year (if available); Abstract Number (optional), Pagination (optional).

[6] Author 1, A.B. (Year). Title of Thesis. Level of Thesis, Degree-Granting University, Location of University, Date of Completion.

[7] Abdillah, M.R., Lin, C.-T., Anita, R., Suroto, B., \& Hadiyati. (2018). Knowledge-sharing behavior among banking officers in Indonesia. Journal of International Studies, 11(2), 136-153. doi:10.14254/2071-8330.2018/11$2 / 10$.

[8] Febriadi, Bayu. 2017. Efisiensi Sistem Informasi berbasis Online Dalam pengumpulan RPKPS mata Kuliah Untuk Pengembangan Kompetensi Program Studi" Vol 8, No. 1, Digital Zone, Jurnal teknologi Informasio dan Komunikasi.

[9] Febriadi, Bayu. 2019. Internal Quality Audit Administration Information System in Badan Penjaminan Mutu. Vol. 2. No 2. Ijistech.Org 2019

[10] Title of Site. Available online: URL (accessed on Day Month Year). 


\section{Authors}

$\mathbf{1}^{\text {st }}$ Author

Bayu Febriadi

Department of Information System

Faculty of Computer Science, Universitas Lancang Kuning 